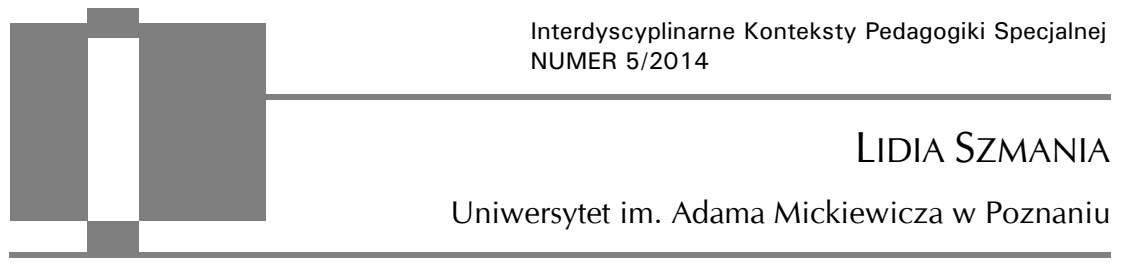

\title{
Doświadczenia emocjonalne rodziców dzieci $z$ autyzmem
}

\begin{abstract}
Szmania Lidia, Emotional experiences of parents of children with autism [Doświadczenia emocjonalne rodziców dzieci z autyzmem]. Interdyscyplinarne Konteksty Pedagogiki Specjalnej, nr 5, Poznań 2014. Pp. 69-91. Adam Mickiewicz University Press. ISBN 978-83-232-2866-0. ISSN 2300-391X.

The purpose of this article is to compare the theoretical knowledge with parents' declarations concerning their emotional experiences resulting from the fact of having a child with autism. Main effort was made to indicate factors that affect these experiences, giving them a positive or negative meaning. Understanding the experiences that the parents of children with autism are highly probable to come across is extremely important as it can contribute to designing better supporting system for such families. It can also enhance mothers' and fathers' life satisfaction and increase effectiveness of preventive measures against the burnout phenomenon.
\end{abstract}

KEY WORDS: autism, parents, emotions.

\section{Wprowadzenie}

W ostatnich latach obserwuje się rozwój specjalistycznej wiedzy oraz wzrost zainteresowania społeczeństwa tematem autyzmu. Dawniej diagnoza autyzmu oznaczała życie w samotności, brak akceptacji społecznej oraz szans rozwojowych dziecka. Obecnie sytuacja osób z autyzmem oraz ich rodzin jest lepsza, a szanse na poprawę funkcjonowania dziecka znacznie wzrosły. Mimo wszel- 
kich pozytywnych zmian pozostaje jednak jeszcze wiele przypuszczeń i poszukiwań. Autyzm nadal postrzega się jako złożone, niedostatecznie poznane "zjawisko”, stanowiące zagadkę - zarówno dla naukowców zainteresowanych tematyką owego zaburzenia, jak i praktyków, czyli terapeutów pracujących z osobami z autyzmem. Rodzice dzieci autystycznych stanowią specyficzną grupę osób, pod wieloma względami odmienną od innych. Owa „inność" polega na tym, iż przez kilka pierwszych lat życia dziecka obserwują jego prawidłowy rozwój, snują plany dotyczące przyszłości jego i rodziny, a także marzenia - jak się zdaje - osadzone na realnych podstawach. Rodzice tworzą obraz swojego dziecka, w którym nie ma miejsca na niepełnosprawność. Z drugiej strony, ta grupa rodziców dysponuje czasem na "oswojenie się" z myślą o występowaniu nieprawidłowości w rozwoju dziecka, ponieważ pojawiają się one stopniowo, a rodzice są pierwszymi dostrzegającymi je osobami.

Każda rodzina doświadcza różnego rodzaju trudnych sytuacji, które sprawiają, że u jej członków zmieniają się świat wartości, spojrzenie na innych ludzi oraz siebie samych. Jedną z takich sytuacji jest właśnie zdiagnozowanie u dziecka autyzmu. Jeśli ujmuje się rodzinę systemowo, to należy pamiętać, iż skutki wystąpienia tego zaburzenia u jednego z jej członków dotykają nie tylko jego samego, lecz także pozostałych osób oraz rodziny pojmowanej jako całość. Codzienne życie staje się wówczas niełatwym wyzwaniem, które podejmuje rodzina dziecka, a przede wszystkim jego rodzice (Pisula 2012).

Problematyką doświadczeń emocjonalnych dzieci z niepełnosprawnością od wielu lat interesują się przedstawiciele nauki (m.in. Gałkowski 1995; Marcus 1983; Peeters 1996; Pisula 1999; Twardowski 2008). W ostatnim czasie zrealizowano kilka projektów badawczych, którym przewodniczyły m.in. Ewa Pisula oraz Małgorzata Sekułowicz.

Celem badań E. Pisuli (1998b) było określenie występowania zjawiska wypalenia się sił u rodziców dzieci z autyzmem. Analizie poddano znaczenie różnorodnych czynników (takich jak: płeć rodziców, poziom ich wykształcenia, aktywność zawodowa, sytuacja 
rodzinna i materialna, rodzaj niepełnosprawności występującej u dziecka - autorka badała rodziców dzieci z autyzmem oraz zespołem Downa, płeć dziecka, liczba dzieci w rodzinie) dla postrzegania swojej sytuacji życiowej oraz poziomu lęku rodziców. Badania wykazały, że poziom lęku jest wyższy w grupie rodziców dzieci z niepełnosprawnością niż $\mathrm{w}$ grupie rodziców dzieci pełnosprawnych. Wniosek ten wydaje się bardzo ważny z uwagi na zwiększenie podatności tej grupy rodziców na obniżenie odporności na stres oraz utratę sił.

M. Sekułowicz (2013) w trakcie prowadzonych badań podjęła próbę przedstawienia pozytywnych i negatywnych przeżyć emocjonalnych rodziców dzieci z niepełnosprawnością w perspektywie całożyciowych doświadczeń rodziny. Jeden z głównych wniosków, który nasuwa się po analizie tych badań, odnosi się do poziomu życiowej satysfakcji rodziców dzieci z niepełnosprawnością jako czynnika mającego kluczowe znaczenie dla funkcjonowania członków rodziny.

Celem artykułu jest ukazanie sposobu funkcjonowania rodziny z dzieckiem z autyzmem, przeżyć rodziców na poszczególnych etapach życia: przed diagnozą, po jej otrzymaniu oraz przy stosowaniu oddziaływań wykorzystujących elementy terapii behawioralnej, a także czynników mających wpływ na owe przeżycia, poprzez odniesienie wypowiedzi rodziców do literatury przedmiotu. Praca ta nie ma charakteru badawczego, stanowi jedynie próbę zrozumienia doświadczeń emocjonalnych obserwowanych u rodziców dzieci z autyzmem dzięki skonfrontowaniu ich z teorią. Zaprezentowane informacje pochodzą z najważniejszego źródła: od rodziców - zarówno z literatury biograficznej (Płacz bez łez. Listy rodziców dzieci autystycznych M. Grodzkiej-Gużkowskiej; Oblężenie. Rodzinna wyprawa w świat dziecka autystycznego C. Park; uwagę zwróciły również wypowiedzi matek zawarte w książce Modele zachowań oraz wspótpraca $z$ dziećmi autystycznymi C. Maurice), jak i rozmów z trzema matkami dzieci z autyzmem.

W tym miejscu zostają przedstawione krótka charakterystyka funkcjonowania dzieci oraz struktury systemu rodzinnego. 
Wojtek (6 lat) - dziecko bardzo inteligentne, o szerokim zakresie mowy czynnej i biernej, czujny obserwator. Jest bardzo spokojny, czasami również powolny, niezwykle precyzyjny, co uważa się za jego charakterystyczną cechę. Uczęszcza do ogólnodostępnej „zerówki". Jego matka obecnie nie pracuje, zajmuje się wychowywaniem jedynego syna. Osobą zarabiającą na utrzymanie rodziny jest ojciec dziecka. Rodzina mieszka w małej miejscowości pod Poznaniem.

Julia (7 lat) - wypowiada proste zdania i rozumie proste komunikaty. Bardzo lubi korale oraz inne elementy damskiej biżuterii. Uczęszcza do przedszkola specjalnego. Jej rodzice pracują. Dziewczynka jest najmłodszym, szóstym dzieckiem w rodzinie. Członkowie rodziny są ze sobą bardzo zżyci. Rodzeństwo chętnie pomaga $\mathrm{w}$ opiece nad Julią oraz zdobywa wiedzę na temat autyzmu na kursach i konferencjach. Rodzina mieszka pod Poznaniem.

Tomek (7 lat) - jego zasób słownictwa biernego jest bardzo wąski. Chłopiec nie mówi. Jest jednak dzieckiem pogodnym, lubi pochwały słowne, potrafi okazać zadowolenie z nich. Uczęszcza do przedszkola specjalnego. Rodzinę utrzymuje ojciec. Matka zajmuje się wychowywaniem synów: Tomka i jego starszego o trzy lata brata. Rodzice bardzo starają się traktować synów jednakowo. Obecnie ich największym zmartwieniem jest przyszłość Tomka. Rodzina mieszka w małej miejscowości niedaleko Poznania.

Rozmowy miały charakter anonimowy, dlatego imiona dzieci zostały zmienione. Badania przeprowadzono zgodnie $\mathrm{z}$ założeniami strategii badań jakościowych. Wybrano metodę studium przypadku grupy - rodziców dzieci z autyzmem, podopiecznych Stowarzyszenia na rzecz Osób z Autyzmem ProFUTURO w Poznaniu. Jako technikę badawczą wykorzystano wywiad (Łobocki 2001). Wszystkim matkom na początku rozmowy zadano główne pytania: jakie emocje odczuwała pani przed diagnozą dziecka oraz po jej otrzymaniu?, w jaki sposób postrzega pani terapię dziecka?, jakie emocje odczuwała pani $\mathrm{w}$ momencie rozpoczęcia terapii, a jakie odczuwa pani teraz? Matki opowiadały o swoich doświadczeniach tak długo, jak było to konieczne, $\mathrm{w}$ preferowany przez siebie sposób. Pytania 
dodatkowe, mające na celu rozwinięcie ciekawych wątków poruszonych podczas narracji, zostały zadane na końcu rozmowy. Każdy dialog był nagrywany, a następnie w całości transkrybowany. Rozmowy trwały od jednej do półtorej godziny. Materiał zebrano na potrzeby niepublikowanej pracy licencjackiej, której celem nie było zaprezentowanie wyników badań, lecz przedstawienie wypowiedzi rodziców dzieci $\mathrm{z}$ autyzmem ukazujących historie trzech rodzin doświadczających sytuacji krytycznej.

\section{Emocje doświadczane przez rodziców dziecka $z$ autyzmem}

Rodzice dzieci z autyzmem doświadczają wielu bardzo trudnych, specyficznych dla tej grupy przeżyć. Towarzyszące im emocje są zróżnicowane $\mathrm{w}$ zależności od etapu, na jakim znajduje się dziecko, a wraz z nim jego rodzina. Należy podkreślić, iż każde dziecko dotknięte autyzmem jest inne, każda rodzina tworzy własną, niepowtarzalną historię. Podobne doświadczenia rodzin dzieci autystycznych, takie jak trudne zachowania i specyficzne potrzeby tych dzieci czy specyfika ich wychowywania, sprawiają jednak, że emocje towarzyszące rodzicom $\mathrm{w}$ poszczególnych okresach życia mogą być do siebie zbliżone (Randall, Parker 2010; Pisula 2007).

\section{Czas przed diagnoza}

Rodzice są najczujniejszymi obserwatorami dziecka. To oni jako pierwsi zauważają nietypowe zachowania dziecka, opóźnienia rozwojowe czy też zanik posiadanych wcześniej umiejętności. Na skutek tego, iż dostrzegają problem, którego nie potrafią zdefiniować i wytłumaczyć, narasta w nich niepokój. Intuicyjnie wyczuwają, że rozwój dziecka nie jest prawidłowy (Pisula 2007). Rodzice czują $\mathrm{w}$ tym okresie silny lęk, są zagubieni, zdesperowani. Towarzyszy im również poczucie winy oraz braku kompetencji rodziciel- 
skich - nie wiedzą, w jaki sposób postępować z dzieckiem oraz jak radzić sobie z jego trudnymi zachowaniami (Pisula 2007; Pisula 2010b). Podczas rozmowy matka Wojtka przedstawiła tę kwestię w następujący sposób: „Przed diagnozą bardziej się stresowałam jego trudnymi zachowaniami, bo wydawało mi się, że może to moja wina, że może nie potrafię ułożyć dziecka". Zdarza się również, że rodzice czują się niepotrzebni; kwestionują tym samym własną wyjątkowość dla dziecka (Pisula, Mazur 2007). Trudniej jest im zauważyć objawy przywiązania, czują się uprzedmiotowieni przez dziecko. "Cudzym ramieniem i dłonią posługiwała się jak narzędziem - zupełnie jakby osoba, do której należały, nie istniała” (Park 2003, s. 13). Dodatkowo rodzice mogą odczuwać pozorny brak miłości ze strony dziecka i jego wrogie nastawienie względem siebie, co odczytują najczęściej z zachowań takich jak: szarpanie za włosy, szczypanie, tulenie się z jednoczesnym unikaniem spojrzenia. Takie zachowania mogą pogłębiać ich dezorientację i zagubienie (Olechnowicz 2004). Ból rodziców potęguje dostrzeganie odmienności w zachowaniu oraz rozwoju dziecka $\mathrm{z}$ autyzmem w porównaniu do jego rodzeństwa. „[...] kontrast między moimi dziećmi był dla mnie bardzo oczywisty i jednocześnie sprawiał mi bardzo dużo bólu" (Maurice 2007, s. 500). Rodzice często porównują swoje dzieci z ich prawidłowo rozwijającymi się rówieśnikami. Dostrzegane liczne rozbieżności stanowią dla nich źródło przykrości: „,w kościele odbywało się poświęcenie tornistrów pierwszoklasistów i tak sobie pomyślałam, że on by też mógł iść teraz do szkoły, i oczywiście łzy naszły mi do oczu..." (matka Tomka). Wielu rodziców doświadcza wówczas poczucia krzywdy, wyrażającego się w pytaniach: „dlaczego ja/my?”, „dlaczego mnie/nas to spotyka?”, będącego jednocześnie wyrazem braku akceptacji sytuacji (Pisula 1998a).

Rodzice podkreślają, że uczucia towarzyszące im przed diagnozą są dla nich bardzo trudne. Jako najcięższe z nich jawi się bezradność. „Uczucia... ich się nie da tak po prostu opisać. To było okropne. Człowiek bezradnie patrzył, co dzieje się z dzieckiem, i nic, zupełnie nic nie mógł zrobić - tak się przynajmniej wtedy wydawało" (matka Julii). 
Istnieje również grupa rodziców, która w tym okresie „zamraża” emocje, „odkłada je na później”. Rodzice dostrzegają nieprawidłowości w zachowaniu dziecka i całą swoją energię przeznaczają na działanie, poszukiwanie przyczyn doświadczanych problemów oraz możliwości rozwiązań. „Na początku nie miałam problemów, normalnie to przyjęłam. Stwierdziłam, że jesteśmy w takiej sytuacji i trzeba działać, pozałatwiać, ile się da [...]. Mąż zawsze był przy mnie i powtarzał, że damy radę. Oboje to przyjęliśmy i wiedzieliśmy, że trzeba się z tym pogodzić i działać, to było najważniejsze" (matka Tomka). Inni rodzice nie dopuszczają do siebie myśli o trwałym zaburzeniu. Sądzą, że dziecko przechodzi chwilowy kryzys. "[...] były chwile załamania, które odbierały chęć do życia, ale były i chwile nadziei i złudzeń, że może wszystko to nieprawda" (Grodzka-Gużkowska 1995, s. 27).

Niezaprzeczalne pozostaje to, że odczuwane (lub też początkowo nieodczuwane) przez rodziców emocje stopniowo potęgują się i kumulują. Rodzice są coraz bardziej zmęczeni niepewnością i nieustannym lękiem, dlatego zaczynają szukać pomocy u specjalistów, takich jak: pediatrzy, foniatrzy, psychologowie, psychiatrzy. Dążą do określenia przyczyn problemów oraz otrzymania diagnozy (Pisula 2008; Pisula 2010b). Ponadto rodzice poprzez podejmowane działania poszukują sposobów na „odzyskanie” dziecka: „należała tyleż do nas, co do siebie samej, a my chcieliśmy, żeby była z nami [...], uciekaliśmy się do najwymyślniejszych podstępów, by zdobyć jej fortecę, [...] zwabić w człowieczeństwo" (Park 2003, s. 17).

\section{Otrzymanie diagnozy}

Rodzice podkreślają, że otrzymanie diagnozy to bardzo ważny moment w życiu całej rodziny. Diagnoza pomaga opisać problem, zrozumieć sytuację, określić przyczyny nieprawidłowego rozwoju dziecka i - nade wszystko - daje nadzieję na odzyskanie kontroli nad własnym życiem. Jak jednak wielokrotnie podkreślano, zdia- 
gnozowanie autyzmu u dziecka jest bardzo trudne. Niekiedy proces diagnostyczny trwa kilka lat, a rodzice odbywają długą, męczącą wędrówkę po gabinetach specjalistów. Często zdarza się również, że stawiane są mylne diagnozy, takie jak np. zaburzenia wzroku, niedosłuch (Pisula 1998a). Opóźnienie diagnozy prowadzi do obciążenia emocjonalnego rodziców, którzy odczuwają coraz większe zmęczenie, żal i smutek. Dlatego po otrzymaniu diagnozy autyzmu czują ulgę oraz spadek napięcia. Diagnoza stanowi często potwierdzenie ich przypuszczeń, a także zakończenie trudnego etapu w życiu całej rodziny, przepełnionego obawami, lękiem, niepewnością, bezradnością (Pisula 1998a; Pisula 2007). „Byłam zmęczona psychicznie, czułam ulgę, że wiem już, co mam robić, a wcześniej nie wiedziałam, jak reagować, nie wiedziałam, co mam robić $\mathrm{w}$ takich trudnych momentach" (matka Julii).

W przekonaniu rodziców, otrzymanie diagnozy rozpoczyna okres działań na rzecz dziecka, czas specjalistycznej pomocy, terapii i powrotu rodziny do równowagi. Ponadto stanowi ona motywację do pracy z dzieckiem, zdobywania informacji na temat autyzmu oraz metod pracy terapeutycznej (Pisula 1998a; Pisula 2007). Paradoksalnie, w takich sytuacjach często dochodzi do pomieszania uczuć pozytywnych z negatywnymi, np. nadziei z rozpaczą i lękiem (Pisula 1998a; Randall, Parker 2010). Podczas rozmowy jedna z matek powiedziała: „diagnoza przyniosła mi ulgę, ale pojawił się też lęk, strach przed nowym, nieznanym i... cicha nadzieja, że teraz będziemy mogli pomóc synkowi. Po diagnozie naprawdę mi ulżyło, bo wiedziałam, skąd to wszystko się bierze. Początkowo było we mnie takie niedowierzanie, że to naprawdę się dzieje, że to naprawdę dotyka naszą rodzinę. Ale im więcej czytałam, im więcej się dowiadywałam, tym bardziej dostrzegałam „normalność” w zachowaniach syna, one po prostu były autystyczne - zmieniło się w moim odczuciu pojęcie normy. Dzięki temu też nie denerwowałam się, nie czułam się już winna, nie czułam się złą matką. Po prostu nasze dziecko miało taką przypadłość, taką cechę, i wszyscy musieliśmy nauczyć się z tym żyć" (matka Wojtka). 


\section{Stosowanie terapii z elementami metody behawioralnej}

Kolejnym krokiem po otrzymaniu diagnozy jest rozpoczęcie terapii. Terapia behawioralna to jedna $z$ najskuteczniejszych i najczęściej stosowanych metod wspierania rozwoju dziecka z autyzmem. Wybór rodzaju terapii należy do rodziców. Niekiedy bywa on przypadkowy. Często rodzice świadomie decydują się jednak na wykorzystanie owej metody w terapii swojego dziecka: „studiowałam kiedyś psychologię i uczyłam się pracować z osobami uzależnionymi właśnie metodą behawioralną. Przez to wiem, że behawioralna jest skuteczna, że pomaga. [...] Poza tym uważam, że w przypadku dzieci z autyzmem behawioralna jest bazą. Żeby cokolwiek wypracować, dotrzeć do dziecka, ono musi nabyć podstawowe umiejętności, a to zapewnia behawioralna. Wszystkie inne metody (z udziałem zwierząt, stosowanie diety itd.) są ważne i potrzebne, ale, $w$ moim odczuciu, stanowią drugi plan. Fundamentem jest behawioralna. Zresztą badania nad skutecznością tej metody to potwierdzają" (matka Wojtka).

Rodzice dzieci z autyzmem przyznają, iż w początkowej fazie stosowania elementów metody behawioralnej $w$ terapii dziecka doświadczali ambiwalentnych uczuć. $Z$ jednej strony, ujawniają problemy związane $\mathrm{z}$ otrzymaniem informacji na temat owej terapii od negatywnie nastawionych specjalistów. Jak podkreślają, wszystkie osoby odradzające im stosowanie terapii z elementami metody behawioralnej brały pod uwagę osobiste przekonania, a nie wiedzę potwierdzoną badaniami. Rodzice wielokrotnie słyszeli, że w efekcie stosowanej analizy zachowania dziecko stanie się "robotem”. Taka postawa specjalistów, a także ogółu społeczeństwa powoduje poczucie dezorientacji i osamotnienia rodziców. Zastanawiają się oni, gdzie popełniają błąd. Z drugiej strony, kontakt z ludźmi wykorzystującymi metodę poznawczo-behawioralną $\mathrm{w}$ pracy $\mathrm{z}$ dzieć$\mathrm{mi} \mathrm{z}$ autyzmem (zarówno terapeutami, jak i rodzicami) przywraca im nadzieję oraz uwalnia od poczucia winy (Maurice 2007).

Rodzice dzieci $\mathrm{z}$ autyzmem opowiadają o swoich pierwszych odczuciach związanych $\mathrm{z}$ ową metodą $\mathrm{w}$ następujący sposób: 
„Zdziwiły mnie okrzyki terapeutów, głośna, żywa radość z każdego - nawet najmniejszego - sukcesu dziecka. A także to, że to była radość prawdziwa! Podejście terapeutów do rodziców, ich otwartość, chęć pomocy, podejście do dziecka... i to, że już po pierwszych zajęciach były efekty, sprawiło, że czuliśmy, że jesteśmy we właściwym miejscu" (matka Tomka). Rodzice początkowo nie rozumieli, na czym polega terapia. Wydawało im się, iż wymagania stawiane dzieciom przez terapeutki są zbyt wysokie. Już na pierwszych zajęciach przekonywali się jednak, że dziecko potrafi znacznie więcej, niż przypuszczali. Jak deklarują, dzięki temu dostrzegli sens stosowania terapii oraz poczuli ogromną motywację do działania i dalszej pracy z dzieckiem.

Nie bez znaczenia jest także obecność kompetentnych terapeutów, służących radą, udzielających rodzicom licznych wskazówek i podpowiadających sposoby postępowania z dzieckiem. „Każde słowo terapeutki było dla mnie cenne" (Grodzka-Gużkowska 1995, s. 64). Pomoc terapeutów powoduje znaczny wzrost poczucia kompetencji rodziców (Grodzka-Gużkowska 1995).

Rodzice twierdzą, że głównymi uczuciami, których doświadczają podczas stosowania terapii poznawczo-behawioralnej, są radość, poczucie spełnienia, satysfakcja. Cieszą się z odnoszenia przez dziecko sukcesów, zdobywania przez nie nowych umiejętności. Czują z tego powodu dumę. ",[...] serce mi się raduje, jak widzę, jak liczy, dopasowuje... jest mi dużo lżej" (matka Julii). Ponadto rodzice dostrzegają, że sukcesy mają znaczenie również dla samych dzieci. Terapia behawioralna jest dla dzieci zrozumiała, przewidywalna, a wykorzystywane elementy stanowią dla niektórych z nich motywację i nagrodę samą w sobie (Park 2003). Ze względu na skuteczność terapii rodzice mają poczucie dobrze spełnionego obowiązku, a także świadomość, iż zrobili wszystko, by zapewnić dziecku pomoc i możliwość rozwoju. „Przeszliśmy razem bardzo długą i trudną drogę, pełną obaw i niepowodzeń. [...] Wydaliśmy tysiące na terapię, warsztaty, konsultacje i materiały. Czy znowu podjęłabym to ryzyko? Absolutnie tak. Czy zarekomendowalibyśmy ten rodzaj terapii innym rodzinom [...]? Bez wątpienia. [...] wiem, że to była 
najlepsza życiowa decyzja. Ta forma terapii w przypadku syna zdziałała cuda" (Maurice 2007, s. 494). Podczas rozmowy matka Wojtka wyznała: „[...] teraz jestem szczęśliwa, że mam takiego syna, i nie zamieniłabym go na nikogo innego. Naprawdę. On jest wspaniały, tak idzie do przodu, jest po prostu wyjątkowy. Z perspektywy czasu widzę, że autyzm to nic strasznego".

Należy jednak pamiętać o tym, że rodzice dzieci z autyzmem są narażeni na chroniczny stres, spowodowany brakiem społecznego zrozumienia, tolerancji i akceptacji specyficznych zachowań dziecka. Doświadczają go na skutek czynników ukazanych w tabelach nr 1 i 2. Stres rodzicielski można zdefiniować jako kompleks ogromnych obciążeń odczuwanych przez rodziców w związku z rolą, którą odgrywają (Pisula 2007). Cechą odróżniającą stres rodzicielski od innych jest „charakter wymagań związanych z opieką nad własnym dzieckiem, a także duży wpływ tych wymagań na tożsamość i poczucie własnej wartości rodziców" (Pisula 2007, s. 42). Cechy charakterystyczne stresu rodzicielskiego zostały przedstawione na rysunku $\mathrm{nr} 1$.

\section{Charakterystyczne cechy}

1. Permanentny charakter

2. Ograniczone możliwości zmiany sytuacji

3. Wieloletnia zależność innej osoby od opieki

4. Bezpośredni związek z istotnym obszarem tożsamości jednostki

5. Silny wpływ na poczucie własnej wartości

6. Poczucie braku kompetencji niezbędnych do sprostania wymaganiom

7. Obciążenia związane z kontaktem z profesjonalistami

\section{Konsekwencje}

1. Wpływ na kondycję psychiczną dziecka i jego rozwój

2. Wpływ na dobrostan rodziców

3. Wpływ na wszystkich członków rodziny i relacje między nimi

4. Wpływ na inne relacje społeczne rodziców

Rys. 1. Charakterystyka stresu rodzicielskiego

Źródło: Pisula 2007, s. 43. 


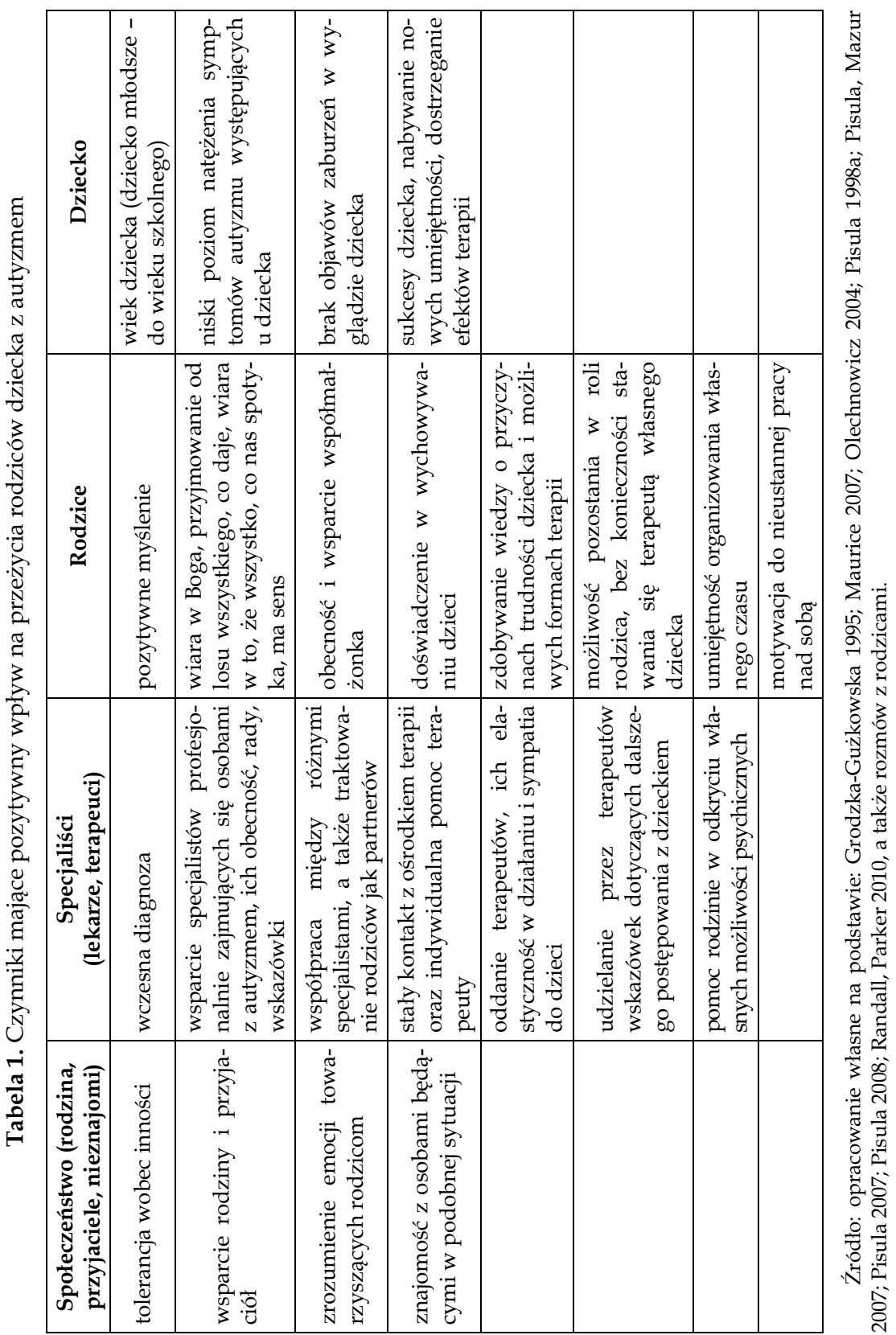




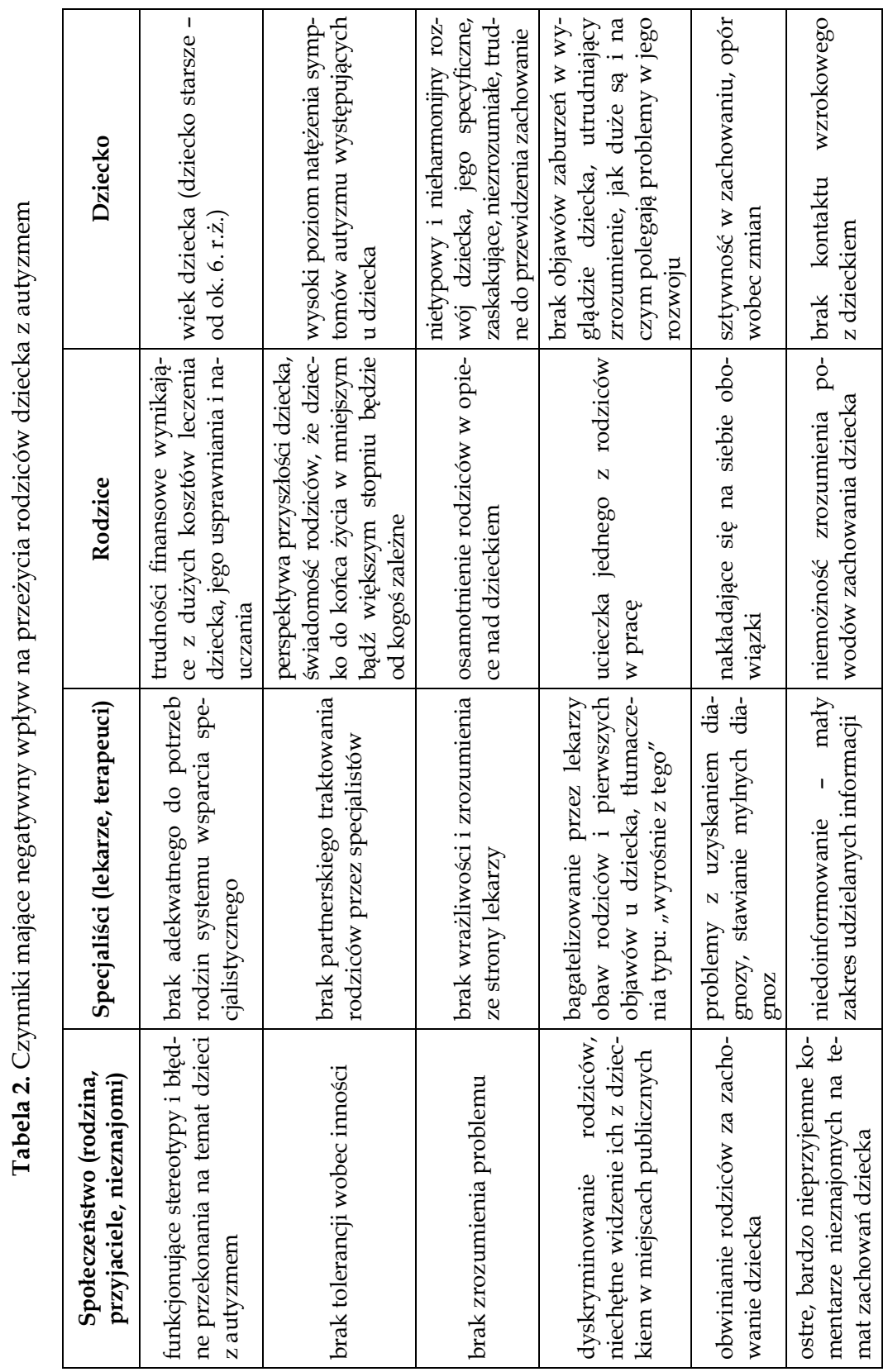


ำ

\begin{tabular}{|c|c|c|c|c|c|c|}
\hline 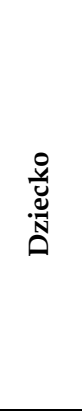 & 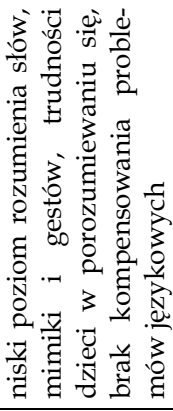 & 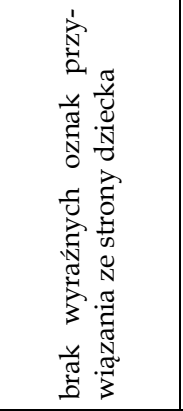 & & & & \\
\hline $\begin{array}{l}\stackrel{\mathscr{V}}{N} \\
\stackrel{0}{0} \\
\cong\end{array}$ & 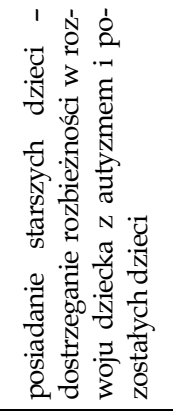 & 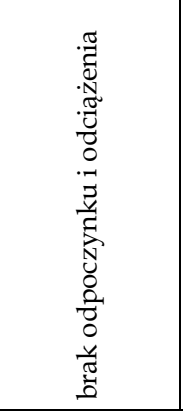 & 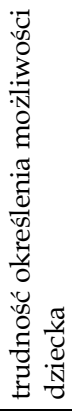 & 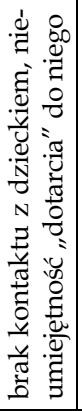 & 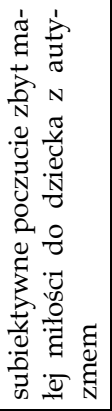 & 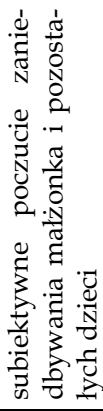 \\
\hline 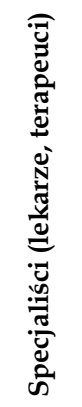 & 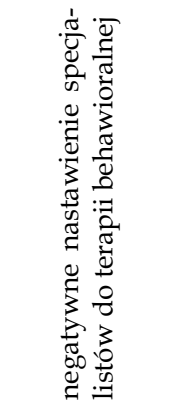 & 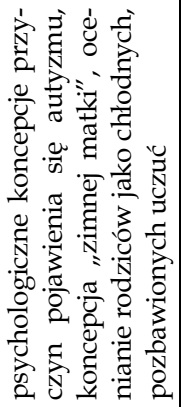 & & & & \\
\hline 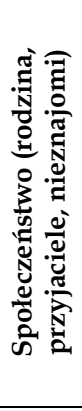 & 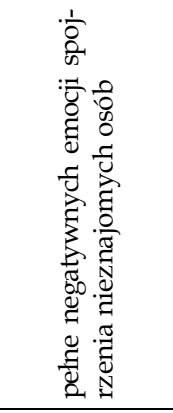 & & & & & \\
\hline
\end{tabular}

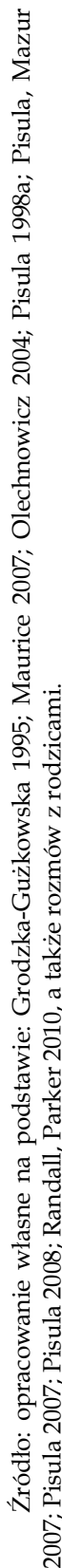


Jedną z możliwych konsekwencji chronicznego stresu występującego u rodziców dziecka $\mathrm{z}$ autyzmem jest zespół wypalenia się sił. Objawia się on utratą sił fizycznych i/lub psychicznych, brakiem motywacji, wrażeniem pustki oraz niedostatku. Rodzice czują się przeciążeni opieką nad dzieckiem, zmęczeni, osamotnieni. Zespołowi wypalenia się sił sprzyjają poczucie wyizolowania rodziny na skutek specyficznych zachowań dziecka oraz niezadowalająca rodziców jakość kontaktów ze specjalistami, którzy zaniedbują ich potrzeby. Na wypalenie się sił szczególnie narażeni są rodzice nieotrzymujący wystarczającego wsparcia - zarówno formalnego (instytucjonalnego), jak i nieformalnego (od pozostałych członków rodziny oraz osób bliskich; Pisula 2008).

W podsumowaniu powyższych rozważań i na podstawie analizy wypowiedzi rodziców należy stwierdzić, że kiedy stają oni w obliczu trudnej sytuacji, odczuwają wiele zróżnicowanych (pozytywnych i negatywnych) emocji w różnych okresach życia dziecka. Paradoksalnie, emocje te często pozostają ze sobą w związku (np. jednoczesne poczucie zasmucenia, ulgi i radości). Przeżycia te są uwarunkowane przez czynniki, które przedstawiono poniżej.

\section{Czynniki mające wpływ na przeżycia rodziców dziecka $\mathrm{z}$ autyzmem}

Trudności, które spotykają rodziców dzieci z autyzmem, oraz specyficzne przeżycia stanowiące ich konsekwencje są uwarunkowane przez splot czynników wewnętrznych i zewnętrznych, pochodzących z różnych źródeł. W niniejszej pracy przyjęto podział na: społeczeństwo, specjalistów, rodziców oraz dziecko. Należy podkreślić, iż tak jak każda rodzina doświadcza różnych przeżyć, tak też wywołujące je czynniki są różnorodne. Co więcej, ten sam czynnik może mieć znaczenie pozytywne bądź negatywne - w zależności od sposobu postrzegania go przez daną rodzinę. Ponadto warto pamiętać o tym, że pomiędzy rodzinami istnieją liczne różnice indywidualne $\mathrm{w}$ sposobie przeżywania sytuacji życiowej, po- 
strzegania związanych z nią wyzwań, stosowanych sposobów radzenia sobie $\mathrm{z}$ trudnymi sytuacjami, a także ze względu na odmienne osobowości członków rodziny (Pisula 2007). Poza tym rodziny różnią się między sobą „możliwościami sprostania wyzwaniom związanym z opieką nad dzieckiem oraz dostępem do źródeł wsparcia" (Pisula 2007, s. 42).

$\mathrm{W}$ tabelach nr 1 i 2 przedstawiono czynniki mające wpływ na przeżycia rodziców dzieci z autyzmem. Jak wynika z zestawionych informacji, rodzice dostrzegają znacznie więcej czynników o zabarwieniu negatywnym niż pozytywnym. Należy również zwrócić uwagę na to, że najwięcej czynników ma swoje źródło w wewnętrznych odczuciach rodziców.

Informacje zaprezentowane $\mathrm{w}$ tabeli $\mathrm{nr} 1$ ukazują czynniki wpływające na przeżycia rodziców dziecka z autyzmem w sposób pozytywny. Rodzice za najważniejsze i najbardziej znaczące uznają wsparcie ze strony współmałżonka, przyjaciół oraz specjalistów, a także pozytywne myślenie i sukcesy odnoszone przez dziecko. Tabela nr 2 prezentuje czynniki negatywnie wpływające na przeżycia rodziców dziecka z autyzmem. Najbardziej akcentowane przez rodziców są: brak społecznej tolerancji, funkcjonujące stereotypy, niedoinformowanie rodziców przez specjalistów, przeciążenie i osamotnienie w opiece nad dzieckiem, brak objawów zaburzenia przejawiającego się w wyglądzie dziecka. Warto zauważyć, iż w celu zmniejszenia wpływu czynników negatywnych należy zaoferować rodzicom to, czego potrzebują najbardziej - wsparcie ze strony rodziny, przyjaciół, specjalistów, a także zrozumienie, społeczną akceptację i pomoc. Może się to przejawiać np. w odciążeniu rodziców w opiece nad dzieckiem, udzielaniu wskazówek oraz rad, a także $w$ poświęconym czasie i rozmowie.

Posiadanie dziecka $z$ autyzmem wpływa negatywnie na funkcjonowanie rodziny $w$ pewnych aspektach życia. Niewiele uwagi poświęca się jednak tym rodzicom, którzy dzięki pomocy i wsparciu życzliwych ludzi uzyskali życiową równowagę, potrafili wskazać dobre strony swojej sytuacji, pozytywne zmiany zachodzące $\mathrm{w}$ nich samych, a także $\mathrm{w}$ relacjach $\mathrm{z}$ innymi ludźmi, za przyczyną 
pojawienia się $\mathrm{w}$ rodzinie dziecka $\mathrm{z}$ autyzmem (Olechnowicz 2004; Pisula 1998a). Pozytywny i negatywny wpływ posiadania dziecka $\mathrm{z}$ autyzmem na funkcjonowanie rodziny jako całości oraz wzajemne relacje przedstawiono w kolejnej części opracowania.

\section{Wpływ posiadania dziecka z autyzmem na funkcjonowanie rodziny}

Obecność dziecka $\mathrm{z}$ autyzmem $\mathrm{z}$ całą pewnością wywiera wpływ na całą rodzinę. Z literatury oraz rozmów przeprowadzonych z rodzicami wynika, iż może on być zarówno pozytywny, jak i negatywny - w zależności od licznych zmieniających się czynników, do których zalicza się m.in.: rozpatrywaną w danym momencie sferę życia, wcześniejsze doświadczenia, przeżycia oraz inne czynniki, przedstawione powyżej (Pisula 1998a).

Wychowywanie dziecka $\mathrm{z}$ autyzmem jest dla rodziców trudnym zadaniem, sytuacją problemową, z którą mogą oni sobie radzić lepiej lub gorzej (Grodzka-Gużkowska 1995). Bardzo ważną rolę odgrywa tu jakość związku rodziców. Może ona stanowić swoisty bufor przeciwko stresowi, ochronę przed wszelkiego rodzaju zagrożeniami (Pisula 1998a). Rodzice za najważniejsze uznają wzajemne wspieranie się, zaufanie, oddanie oraz zrozumienie. $W$ trakcie przeprowadzonej rozmowy jedna z matek przyznała, iż trudne przeżycia cementują związek, pozwalają zrozumieć, na czym naprawdę polega małżeństwo. Ponadto według rodziców, dziecko autystyczne jeszcze bardziej jednoczy rodzinę, uczy jej członków pomagania sobie, wspólnego organizowania czasu, równego podziału obowiązków oraz wiary w to, że „ciężar jest dużo lżejszy, gdy dźwiga się go razem” (matka Tomka). Matka Wojtka wyznała: "Syn jest owocem naszej miłości, więc połączył nas tak, jak każde dziecko łączy dwoje kochających się ludzi, sprawił, że staliśmy się prawdziwą rodziną". Należy jednak podkreślić, że zdarzają się sytuacje, w których na skutek zdiagnozowania autyzmu u dziecka, codziennego przemęczenia oraz braku czasu dla siebie nawzajem 
więź emocjonalna między małżonkami słabnie. Rodzice czują się osamotnieni, obwiniają się wzajemnie za sytuację, w której przyszło im żyć (Randall, Parker 2010).

Występowanie autyzmu u dziecka może negatywnie wpływać na wzajemność uczuć oraz obniżać poziom empatii w relacji rodzic - dziecko (Randall, Parker 2010). Jak jednak twierdzą rodzice, na skutek wzmożonej opieki nad dzieckiem z autyzmem, poświęcania mu większej ilości czasu i uwagi czują z nim silniejszą więź, większą bliskość. Są również bardziej wyczuleni na wszelkie oznaki miłości oraz przywiązania ze strony dziecka. Bardzo często bywa tak, że dziecko $\mathrm{z}$ autyzmem znajduje się w centrum życia rodziny, co potwierdza wypowiedź jednej z matek: "córka jest rozpieszczana, jest naszym oczkiem w głowie. Dostaje taką porcję miłości, że inne dzieci mogą jej zazdrościć" (matka Julii). W sytuacji posiadania większej liczby dzieci trudne i męczące może być nieustanne przechodzenie $\mathrm{z}$ roli rodzica dziecka $\mathrm{z}$ autyzmem do roli rodzica pozostałych dzieci. Rodzice starają się jednakowo traktować wszystkie swoje dzieci, ale jednocześnie chcą najpierw zaspokajać potrzeby dziecka autystycznego (Randall, Parker 2010). Taka postawa oraz mała ilość czasu poświęcana pozostałym dzieciom może skutkować pojawianiem się konfliktów między nimi a rodzicami (Pisula 1998a). Rodzice zauważają, że ogólna sytuacja rodziny jest dużo łatwiejsza, gdy rodzeństwo włącza się w opiekę nad dzieckiem $\mathrm{z}$ autyzmem. Wtedy oni mają więcej czasu dla siebie nawzajem oraz pozostałych dzieci, nie czują się tak zmęczeni i przeciążeni obowiązkami. Są również spokojniejsi, ponieważ widzą, iż rodzeństwo ma ze sobą kontakt i pozostaje w dobrych relacjach (Park 2003).

Jak deklaruje część rodziców, pojawienie się w rodzinie dziecka z autyzmem nie miało wpływu na ich wcześniejsze przyzwyczajenia związane ze spotkaniami z przyjaciółmi lub z wychodzeniem do kina, teatru, restauracji. Twierdzą oni, że zabierają dziecko wszędzie, bez względu na społeczne reakcje powodowane jego nietypowymi zachowaniami. Jak wyznają, posiadanie dziecka z autyzmem sprawiło, iż „wyselekcjonowała się” grupa ich prawdziwych przyjaciół. Pozostali najwierniejsi, udzielający silnego wsparcia, 
a także pojawili się nowi - rodzice dzieci z autyzmem oraz terapeuci (Grodzka-Gużkowska 1995). Istnieje jednak grupa rodziców, która na skutek zaistniałej sytuacji uległa procesowi izolacji społecznej. Schemat powstawania izolacji społecznej rodzin został przedstawiony na rysunku nr 2. Wynika z niego, iż izolacja ta stanowi konsekwencję obecności trzech czynników źródłowych: negatywnych kontaktów ze specjalistami, wrogości i wyśmiewania dziecka $\mathrm{z}$ autyzmem przez społeczeństwo oraz braku akceptacji własnego dziecka. Izolacja społeczna wpływa niekorzystnie na dziecko, jego rodziców i rodzeństwo. Wszyscy członkowie rodziny czują jej konsekwencje i dla każdego z nich jest ona trudna (Pisula 1998a).

Rodzice mają negatywne Rodzice stykają się z wrogodoświadczenia w kontaktach ścią i wyśmiewaniem właze specjalistami

$\Downarrow$ snego dziecka

$\Downarrow$
Rodzice nie akceptują własnego dziecka

$\Downarrow$

Rodzice boją się kontaktów z innymi ludźmi

$\Downarrow$

Rodzice unikają kontaktów własnych i dziecka z otoczeniem

$\Downarrow$

Otoczenie nie zna problemów rodziców i dziecka, odczuwa lęk przed dzieckiem o zaburzonym rozwoju

$\Downarrow$

Otoczenie unika kontaktów $z$ dzieckiem i jego rodzicami

Rys. 2. Powstawanie izolacji społecznej rodziny z dzieckiem o zaburzonym rozwoju Źródło: Pisula 1998a, s. 26.

Ponadto rodzice dostrzegają wpływ posiadania dziecka z autyzmem na siebie samych, mają świadomość wewnętrznych zmian, które w nich zaszły. Przypisują im pozytywny charakter. Twierdzą, iż dziecko nauczyło ich tolerancji, empatii, cierpliwości, wyrozumiałości, a także zwiększyło ich pokłady miłości. Dzięki wyjątkowej sytuacji, w jakiej znalazła się rodzina, rodzice doświadczają swojego rozwoju osobistego: zdobywają wiedzę na temat zaburzenia, uczest- 
niczą $\mathrm{w}$ różnych kursach i szkoleniach, czytają fachową literaturę, rozpoczynają studia, podejmują pracę (Grodzka-Gużkowska 1995).

W literaturze można znaleźć następujące wypowiedzi rodziców dzieci autystycznych: "[autyzm to] narzędzie, które miało mnie nauczyć pokory” (Park 2003, s. 47), „kochamy go takim, jaki jest; jesteśmy bogatsi psychicznie" (Grodzka-Gużkowska 1995, s. 165) oraz „wychowanie dziecka upośledzonego wymaga wielu wyrzeczeń, ale jednocześnie czyni nasze życie bogatszym i bardziej wartościowym. Dla nas synek jest prawdziwym aniołem, bo tylko anioły czynią ludzi lepszymi" (Grodzka-Gużkowska 1995, s. 228). Stanowią one najlepszy dowód na to, iż rodzice potrafią dostrzec pozytywne strony swojego wyjątkowego rodzicielstwa.

Autyzm wywiera wpływ na funkcjonowanie całej rodziny, na każdego jej członka z osobna i na relacje wewnątrzrodzinne. Wpływ ten nie musi jednak być negatywny. Wiele zależy od przeżyć rodziców oraz wywołujących je czynników. Dodatkowo warto pamiętać, iż nie wszystkie utrudnienia pojawiające się $\mathrm{w}$ życiu rodziny muszą mieć swoje źródło w zaburzonym rozwoju dziecka, co potwierdzają słowa jednej z matek: „Wierzę, że rodziny z autystycznymi dziećmi nie są bardziej ani mniej szczęśliwe od rodzin w ogóle, a jeśli są nieszczęśliwe, nie wynika to koniecznie z autyzmu" (Akerley, za: Pisula 1998a, s. 151).

\section{Podsumowanie}

Pozyskane informacje pozwalają stwierdzić, że na skutek posiadania dziecka $\mathrm{z}$ autyzmem rodzice doświadczają zarówno negatywnych, jak i pozytywnych, wzbogacających przeżyć. Nie istnieje rodzina odczuwająca wyłącznie pozytywne lub negatywne emocje. Uczucia te zmieniają się i przeplatają.

Czas poprzedzający otrzymanie diagnozy wiąże się z doświadczaniem przez rodziców wielu przeżyć negatywnych. Przeanalizowana literatura biograficzna oraz przeprowadzone rozmowy ujawniają, iż do charakterystycznych emocji odczuwanych przez rodziców 
w tym okresie należą: niepokój, silny lęk, zagubienie, zdesperowanie, poczucie winy i braku miłości ze strony dziecka, dezorientacja we własnej sytuacji życiowej, zmęczenie, smutek, ból spowodowany dostrzeganiem rozbieżności $\mathrm{w}$ rozwoju dziecka $\mathrm{z}$ autyzmem oraz jego rówieśników lub pozostałych dzieci w rodzinie. Jak podkreślają rodzice, najtrudniejsze jest dla nich poczucie bezradności oraz braku rodzicielskich kompetencji, pojawiające się na skutek nieumiejętności wyjaśnienia przyczyn nietypowego zachowania dziecka oraz poradzenia sobie z nim. Negatywne przeżycia rodziców są pogłębiane w efekcie nieprzyjemnych uwag nieznajomych na temat zachowań dziecka, braku zrozumienia i tolerancji, funkcjonujących w społeczeństwie stereotypów, stawiania mylnych diagnoz, braku wsparcia specjalistycznego, niedoinformowania, osamotnienia w opiece nad dzieckiem, braku odpoczynku oraz odciążenia, a także wysokiego poziomu natężenia symptomów autyzmu i specyficznych, trudnych do przewidzenia zachowań dziecka. Jedną z możliwych konsekwencji negatywnych przeżyć rodziców jest stres rodzicielski, mogący skutkować wypaleniem się sił.

Zebrane informacje pokazują, że w momencie otrzymania diagnozy rodzice doświadczają wielu sprzecznych, choć - paradoksalnie - powiązanych ze sobą uczuć. Z jednej strony, czują smutek, żal i załamanie $\mathrm{z}$ uwagi na wystąpienie autyzmu u dziecka, z drugiej zaś - ulgę i radość, ponieważ skoro wiadomo już, co jest przyczyną zaburzenia rozwoju dziecka, to będzie można rozpocząć terapię. W tej sytuacji bardzo pomocne okazują się wsparcie i zrozumienie ze strony współmałżonka, a także udzielanie przez specjalistów wskazówek dotyczących postępowania z dzieckiem. Jak podkreślają rodzice, bardzo ważne są w tym czasie: pozytywne myślenie, wiara w Boga, przekonanie, że wszystko ma swój głębszy sens. Rodzicom szczególne trudności sprawiają wtedy nieumiejętność określenia możliwości rozwojowych dziecka oraz brak partnerskiego traktowania przez specjalistów.

Rodzice dzięki podjętym działaniom terapeutycznym dostrzegają możliwości swojego dziecka, wzmacniają kontakt uczuciowy z nim, przez co czują się spełnieni, szczęśliwi i kompetentni. Znajomość 
osób będących w podobnej sytuacji, stały kontakt z ośrodkiem terapii, indywidualna pomoc terapeuty, możliwość pozostania $\mathrm{w}$ roli rodzica bez konieczności stawania się terapeutą własnego dziecka, a także jego sukcesy, nabywanie nowych umiejętności oraz dostrzeganie efektów terapii pomagają im spojrzeć na swoją sytuację w sposób pozytywny. Czynniki takie jak negatywne nastawienie specjalistów do wybranego rodzaju terapii oraz trudności finansowe wynikające $z$ dużych kosztów usprawniania i nauczania dziecka stanowią natomiast dodatkowe obciążenie emocjonalne. Rodzice potrzebują tu wsparcia - zarówno od osób bliskich, jak i ze strony instytucji oraz terapeutów.

Wielu rodziców wskazuje liczne pozytywne zmiany, które zaszły w nich samych na skutek posiadania dziecka z autyzmem. Jak twierdzą, stali się bardziej tolerancyjni, empatyczni, cierpliwi i wyrozumiali. Ich życie zostało przewartościowane, priorytety się zmieniły. Doszło do umocnienia się więzi rodzinnych, poszerzenia się sieci społecznej. Nastąpił rozwój duchowy członków rodziny.

Przeżycia rodziców związane z diagnozą i terapią dziecka z autyzmem są trudne, jednak życie tych rodzin może być szczęśliwe. Jak stwierdziła matka Wojtka, warto postrzegać taką rodzinę jako mającą "INNE problemy, na które znajduje się po prostu INNE rozwiązania".

Należy podkreślić, iż zebrany materiał to jedynie próba zaprezentowania historii mających $\mathrm{u}$ podstaw doświadczenia emocjonalne kilku rodzin. Ich narracja, choć zgodna z literaturą przedmiotu, jest subiektywna i nie podlega możliwości uogólnienia. Jednocześnie wydaje się, że informacje zgromadzone w artykule mogą stanowić podstawę do przeprowadzenia badań na reprezentatywnej grupie.

Bibliografia

GrodZKA-GuŻKOWSKA M., Płacz bez łez. Listy rodziców dzieci autystycznych, Prószyński i S-ka, Warszawa 1995.

Łовоскі M., Wprowadzenie do metodologii badań pedagogicznych, Oficyna Wydawnicza Impuls, Kraków 2001. 
Modele zachowań oraz wspótpraca z dziećmi autystycznymi, red. C. Maurice, Fundacja Adama, Warszawa 2007.

OleChNOWICZ H., Wokót autyzmu. Fakty, skojarzenia, refleksje, WSiP, Warszawa 2004.

PARK C., Oblężenie. Rodzinna wyprawa w świat dziecka autystycznego, Wydawnictwo Literackie, Kraków 2003.

PISUlA E., Autyzm. Przyczyny, symptomy, terapia, Wydawnictwo Harmonia, Gdańsk 2010b.

PISUlA E., Dzieci z autyzmem, [w:] Dziecko niepetnosprawne w rodzinie, red. I. Obuchowska, WSiP, Warszawa 2008.

PISUlA E., Psychologiczne problemy rodziców dzieci z zaburzeniami rozwoju, Wydawnictwa Uniwersytetu Warszawskiego, Warszawa 1998a.

PISUlA E., Rodzice dzieci z autyzmem, Wydawnictwo Naukowe PWN, Warszawa 2012.

PISULA E., Rodzice i rodzeństwo dzieci z zaburzeniami rozwoju, Wydawnictwa Uniwersytetu Warszawskiego, Warszawa 2007.

Pisula E., Stres rodzicielski $i$ zespót wypalenia się u rodziców dzieci autystycznych, „Dziecko Autystyczne”, 1998b, t. VI, nr 1.

PISULA E., MAZUR A., Jak matki postrzegaja swoje dzieci z autyzmem? Jakościowa analiza wypowiedzi matek, [w:] Rodzina z dzieckiem z niepetnosprawnościa, red. E. Pisula, D. Danielewicz, Wydawnictwo Harmonia, Gdańsk 2007.

RANDALl P., PARKER J., Autyzm. Jak pomóc rodzinie, Gdańskie Wydawnictwo Psychologiczne, Sopot 2010.

SEKUŁOWICZ M., Wypalenie się sił rodziców dzieci z niepetnosprawnościa, Wydawnictwo Naukowe Dolnośląskiej Szkoły Wyższej, Wrocław 2013.

TWARDOWSKI A., Sytuacja rodzin dzieci niepetnosprawnych, [w:] Dziecko niepetnosprawne w rodzinie, red. I. Obuchowska, WSiP, Warszawa 2008. 